\title{
Telenomus remus Nixon Egg Parasitization of Three Species of Spodoptera Under Different Temperatures
}

\author{
Af Pomari ${ }^{1}$, AF Bueno ${ }^{2}$, RCOF Bueno ${ }^{3}$, AO Menezes $\mathrm{Jr}^{4}$ \\ ${ }^{1}$ Fac de Filosofia, Ciências e Letras, Univ de São Paulo, Ribeirão Preto, SP, Brasil \\ ${ }^{2}$ Embrapa Soja, Londrina, PR, Brasil \\ ${ }^{3}$ Depto de Produção de Plantas, Univ Estadual Paulista (UNESP), Botucatu, SP, Brasil \\ ${ }^{4}$ Univ Estadual de Londrina (UEL), Londrina, PR, Brasil
}

\author{
Keywords \\ Biological control, egg parasitoid, fall armyworm, \\ southern armyworm, velvet armyworm

\section{Correspondence} \\ AF Bueno, EMBRAPA SOJA, Rod. Carlos \\ João Strass-Distrito de Warta, Caixa Postal \\ 231, 86001-970 Londrina, PR, Brasil; \\ adeney.bueno@embrapa.br \\ Edited by Madelaine Venzon - EPAMIG \\ Received 26 May 2012 and accepted 16 \\ April 2013 \\ Published online 31 May 2013 \\ (C) Sociedade Entomológica do Brasil 2013
}

\begin{abstract}
Telenomus remus Nixon is a promising biocontrol agent as an egg parasitoid of Spodoptera spp., but the lack of information on the host-parasitoid interactions in this system precludes its applied use in agriculture. Therefore, we studied the parasitism capacity of $T$. remus on eggs of Spodoptera cosmioides (Walker), Spodoptera eridania (Cramer), and Spodoptera frugiperda (Smith) in a range of temperatures (19, 22, 25, 28,31 , and $\left.34 \pm 1^{\circ} \mathrm{C}\right)$ under controlled conditions $(70 \pm 10 \% \mathrm{RH}$ and $12 \mathrm{~h}$ photophase). Egg masses of Spodoptera spp. were offered to a singlemated $T$. remus female on a daily basis. More than $80 \%$ lifetime parasitism on eggs of S. cosmioides, S. frugiperda, and S. eridania was reached from 1 to 5,1 to 7 , and 1 to 9 days, respectively, at temperatures from 19 to $34^{\circ} \mathrm{C}$. More than $80 \%$ parasitization was obtained at extreme temperatures for all hosts studied. Lifetime parasitization of S. frugiperda, S. cosmioides, and $S$. eridania was affected by temperature, with the lowest values for $S$. frugiperda $\left(34^{\circ} \mathrm{C}\right)$ and $S$. cosmioides $\left(19\right.$ and $\left.34^{\circ} \mathrm{C}\right)$. Parasitization of $S$. eridania eggs was reduced around $18 \%$ at 28 and $31^{\circ} \mathrm{C}$, but dropped more severely at $34^{\circ} \mathrm{C}$. Parasitoid longevity was reduced as temperature increased. Thus, our data indicated that $T$. remus might be suitable as a biocontrol agent against S. eridania, S. cosmioides, and S. frugiperda in geographical areas that fit the temperature range studied here, even though $T$. remus parasitism was reduced at $34^{\circ} \mathrm{C}$.
\end{abstract}

\section{Introduction}

Spodoptera spp. (Lepidoptera: Noctuidae) are widely distributed throughout the world. From the 30 species already described in this genus, about half of them are considered pests of several different and economically important crops (Pogue 2002). In Brasil, 15 species of Spodoptera occur as agricultural pests, presenting a high degree of polyphagy, feeding on crops such as cereals and pastures (Pogue 2002), horticultural crops (Silva et al 1968), and eucalyptus (Santos et al 1980). Furthermore, Spodoptera frugiperda (Smith), Spodoptera eridania
(Cramer), and Spodoptera cosmioides (Walker) stand out on the crops such as corn, soybean, and cotton as they cause severe damage (Cruz et al 1999, Nagoshi 2009).

Chemical control is the most used strategy for the management of Spodoptera (Figueiredo et al 1999, Morales et al 2000). However, not only has the large utilization of insecticides selected populations that are resistant to several active ingredients (Diez-Rodriguez \& Omoto 2001), but also has caused environmental imbalances that favor the increase of secondary pests (Stark \& Banks 2003, Desneux et al 2007). In this scenario, the implementation of an Integrated Pest Management (IPM) program is necessary 
in order to mitigate problems triggered by the abusive spraying of chemicals (Figueiredo et al 1999, Ferrer 2001). IPM aims towards the rational use of insecticides as well as the harmonious integration of different control strategies (Zalucki et al 2009). Among the strategies used in IPM programs, a lot of attention has been given to biological control (Ferrer 2001) as it helps to reduce the negative impact of the intensive agriculture on the environment (van Lenteren \& Bueno 2003).

Among the natural enemies of Spodoptera spp., Telenomus remus Nixon (Hymenoptera: Platygastridae) stands out as a highly specialized egg parasitoid (Cave 2000). Its efficiency in controlling the fall armyworm $S$. frugiperda has been proved in countries such as Venezuela and Mexico (Hernández \& Díaz 1996, Cave 2000, Figueiredo et al 2002, Bueno et al 2008). As this parasitoid successfully controls $S$. frugiperda, there is also a chance it may successfully parasitize other species of the same genus, such as $S$. eridania and S. cosmioides, whose economic importance has been increased in recent years (Bueno et al 2010a, b).

However, complementary studies regarding the successful exploitation of such hosts would be needed before the development of biological control programs using T. remus, as well as other studies regarding the biology, climate impact, and parasitization capacity (Figueiredo et al 1999, Higley et al 1986, Bueno et al 2008).

Among several factors affecting the development of natural enemies, thermal adaptation is of major importance since it is known to impair the duration of the developmental period, the sex ratio, the parasitism, and the longevity of adults (Frazer \& McGregor 1992). In some cases, parasitoid performance on different hosts may be affected by temperature as well (Bleicher \& Parra 1990, Hernández et al 1989). Therefore, we aimed to study the parasitism capacity of $T$. remus in different hosts and at different temperatures in order to provide the basic knowledge required for the use of this biological control agent in integrated pest management of the different host species (S. frugiperda, S. eridania, and S. cosmioides). Therefore, this research aimed to evaluate the parasitism capacity of $T$. remus on eggs of those hosts under different temperatures.

\section{Material and Methods}

A bioassay was carried out to study the parasitization capacity of $T$. remus on eggs of $S$. frugiperda, $S$. cosmioides, and S. eridania. Trials were performed under different temperatures $\left(19,22,25,28,31\right.$, and $\left.34 \pm 1^{\circ} \mathrm{C}\right)$ at controlled conditions $(70 \pm 10 \% \mathrm{RH}$ and a photophase of $12 \mathrm{~h})$. A fully randomized experimental design, with treatments arranged in a $3 \times 6$ factorial design (three Spodoptera species $\times$ six temperatures) with 20 replicates were used. Each replicate consisted of a single-mated $T$. remus female (up to 24 -h old) and a fresh egg mass of Spodoptera (up to 24 -h old) placed in a individual plastic vial $(1 \mathrm{~cm} \varnothing \times 6 \mathrm{~cm}$ tall). Egg masses were replaced on a daily basis.

\section{Host and parasitoid rearing}

Insects were obtained from colonies kept at Embrapa Soja, located in Londrina, state of Paraná, Brasil. Spodoptera cosmioides was originally collected on castor bean plants (Ricinus communis) in Pelotas, state of Rio Grande do Sul, and reared for seven generations in the lab before being used in the experiments. Spodoptera eridania was originally collected on soybean plants (Glycine max) in Mamborê, state of Paraná, and reared for eight generations. Spodoptera frugiperda was originally collected on corn plants (Zea mays) in Rio Verde, state of Goiás, and reared for 36 generations before use. Since their field collection, all host species were reared under laboratory-controlled conditions $\left(25 \pm 2^{\circ} \mathrm{C}, 70 \pm 10 \% \mathrm{RH}\right.$, and a photophase of $\left.12 \mathrm{~h}\right)$ and fed on an artificial diet based on beans, wheat germ, and soybean (Greene et al 1976).

Telenomus remus was originally collected in Ecuador in 1986 and it was multiplied at the parasitoid rearing facilities at the Escola Superior de Agricultura "Luiz de Queiroz"/Universidade de São Paulo, and then tranferred to Embrapa Soja where they have been reared for 5 years before being used in this experiment. Telenomus remus has been reared on egg masses of $S$. frugiperda glued onto a cardboard sheet $(2 \times 8 \mathrm{~cm})$. Parasitoids were honey-fed and $T$. remus was allowed to parasitize for $24 \mathrm{~h}$.

\section{Parasitism}

The egg masses (up to 24 -h old) containing nearly 100 eggs of each host were glued on $0.8 \times 5 \mathrm{~cm}$ rectangular cards, and individually introduced into a vial where a single, mated, honey-fed female was available. The cards containing the egg masses were replaced on a daily basis until the female's death. Eggs exposed to parasitization were daily transferred to new glass tubes $(2 \mathrm{~cm} \varnothing \times 8 \mathrm{~cm}$ tall) and maintained at the same temperatures at which the parasitism occurred until adult eclosion.

The tested temperatures were chosen based on Bueno et al (2008), who reported that T. remus development was impaired at 15 and $35^{\circ} \mathrm{C}$. Therefore, this present study aimed at understanding $T$. remus parasitization capacity at temperatures within the range that could be adequate for this parasitoid $\left(19,22,25,28,31\right.$, and $\left.34^{\circ} \mathrm{C}\right)$. 
For each temperature, the following biological parameters were observed: number of daily parasitized eggs, lifetime parasitism (percent and percentage of the total number of eggs parasitized during the parasitoid lifetime), total number of eggs parasitized per female, and parental female longevity (days). The total number of parasitized eggs (lifetime parasitization) and parental female longevity were submitted for evaluation of the assumptions of normality residues (Shapiro \& Wilk 1965), homogeneity of variance of treatments (Burr \& Foster 1972), and additivity of the model to allow for analysis of variance. Means were then compared by Tukey's test at $5 \%$ probability (SAS Institute 2001).
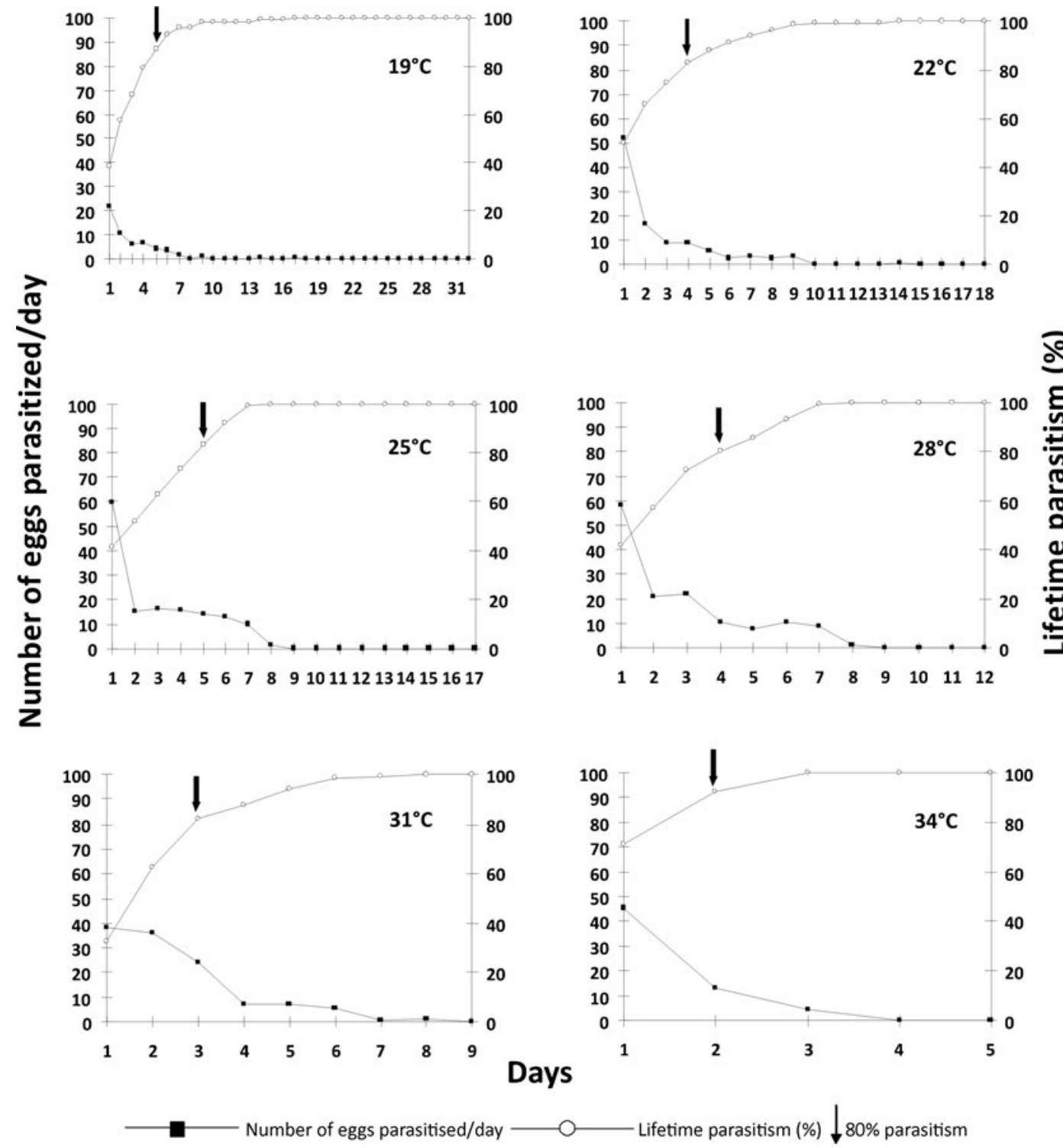

Fig 1 Daily (number) and lifetime parasitism (percentage) of Spodoptera cosmioides eggs by Telenomus remus at different temperatures.

\section{Results}

The number of parasitized eggs per day varied with temperature and host species, but it was higher on the first $24 \mathrm{~h}$ on all studied Spodoptera species and temperatures (Figs 1, 2, and 3). Parasitoids decreased the number of eggs daily parasitized on the studied host species as a function of the time of parasitism and of the temperature at which they were subjected (Figs 1, 2, and 3). More than $80 \%$ of lifetime parasitization of $T$. remus on eggs of $S$. cosmioides (Fig 1), S. frugiperda (Fig 2), and S. eridania (Fig 3) was reached, respectively, from 1 to 5,1 to 7 , and 1 to 9 days, depending on the temperature they were exposed to.
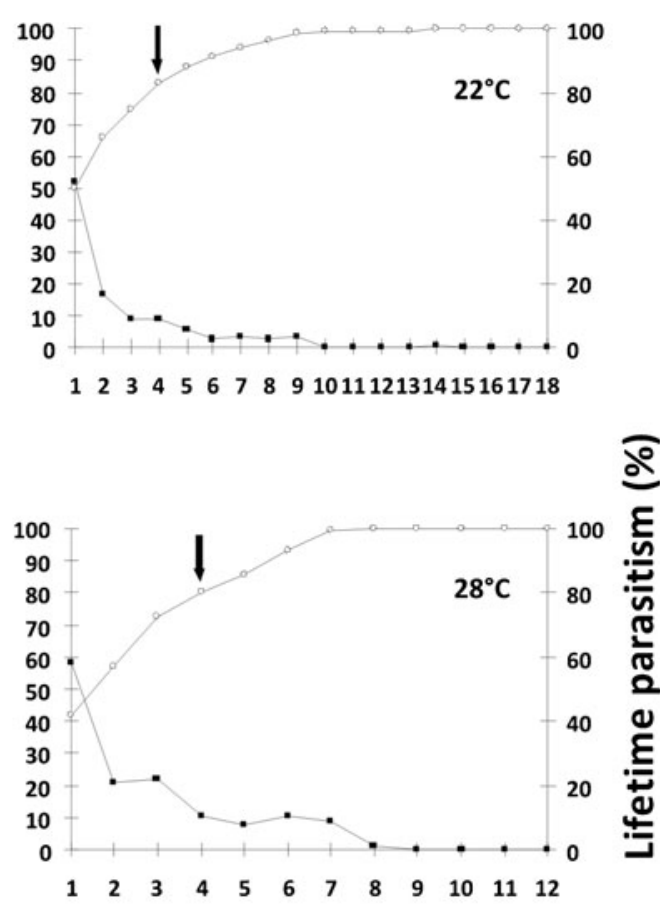

- Lifetime parasitism (\%) $\downarrow 80 \%$ parasitism 


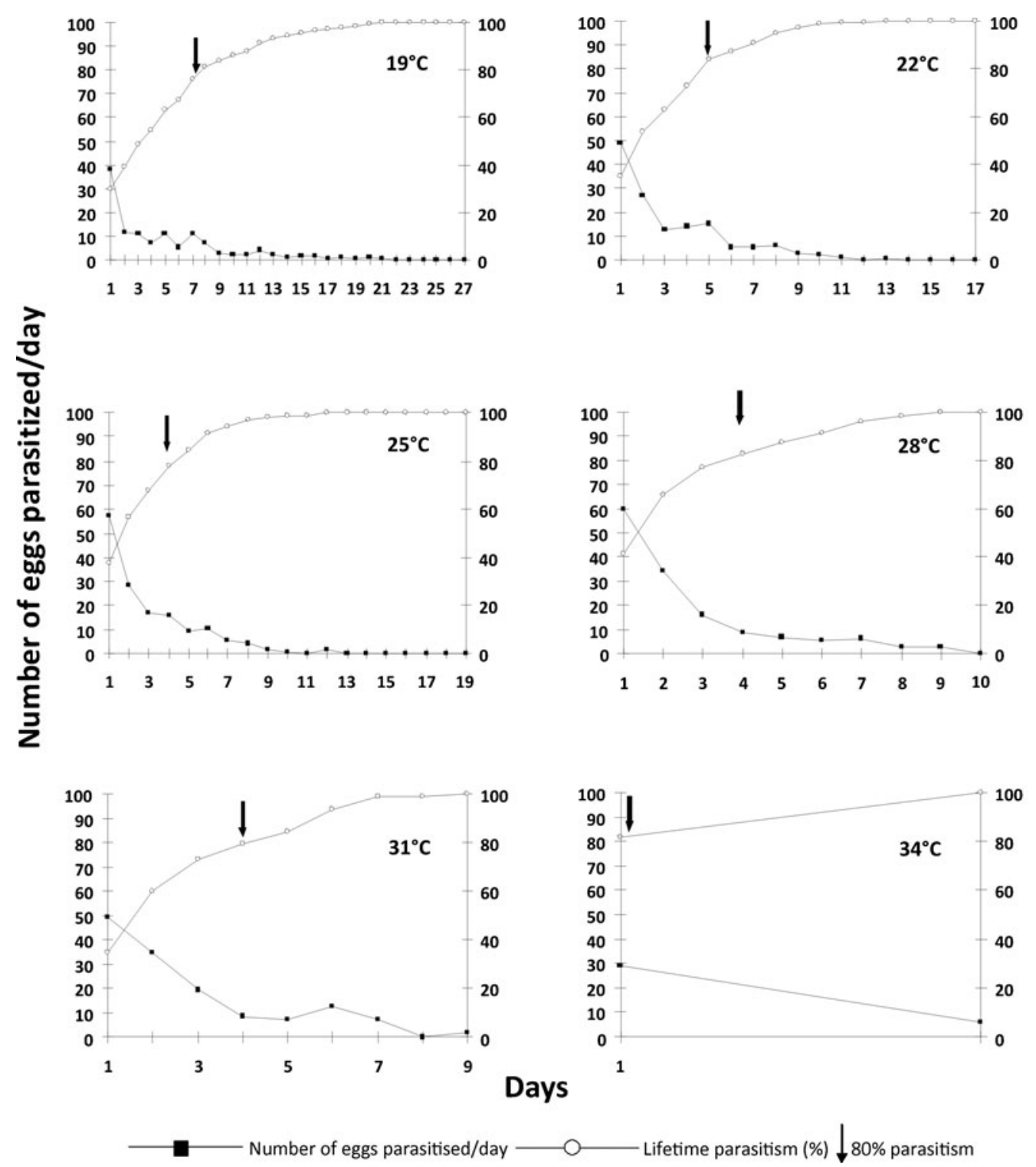

Fig 2 Daily (number) and lifetime parasitism (percentage) of Spodoptera frugiperda eggs by Telenomus remus at different temperatures.

Parental longevity of $T$. remus females when presented with eggs of Spodoptera spp. significantly varied with temperature $(F=323.22, d f=5, p<0.0001)$, with host species $(F=$ 43.07, $d f=2, p<0.0001)$ and with the temperature and host interactions $(F=3.07, d f=10, p=0.0010)$. Parental longevity was inversely proportional to temperature for all studied hosts (Table 1). For all tested temperatures and hosts, $T$. remus females presented to $S$. cosmioides eggs had the highest parental longevity, similar to when $T$. remus females was presented to $S$. eridania eggs at $22^{\circ} \mathrm{C}$ and to both $S$. frugiperda and S. eridania eggs at $34^{\circ} \mathrm{C}$ (Table 1 ).

As a combination of adult longevity associated with parasitoid egg load and host quality, the lifetime number of parasitized eggs varied among temperatures $(F=40.23$, $d f=5, p<0.0001)$, hosts $(F=7.26, d f=2, p=0.0008)$, and the interaction between temperature and hosts $(F=5.79, d f=$ 10, $p<0.0001$; Table 2). Lifetime parasitization of $T$. remus was lower at $34^{\circ} \mathrm{C}$ and no differences were observed from 19 to $31^{\circ} \mathrm{C}$ with eggs of $S$. frugiperda as hosts. Lifetime parasitization on eggs of $S$. cosmioides was reduced at 34 and $19^{\circ} \mathrm{C}$. Differently, however, T. remus lifetime parasitization on S. eridania eggs was reduced around $18 \%$ at $28^{\circ} \mathrm{C}$ and $31^{\circ} \mathrm{C}$, but much more severely at $34^{\circ} \mathrm{C}$ (Table 2).

Regarding the hosts, the lowest parasitism by $T$. remus was observed at $34^{\circ} \mathrm{C}$ on eggs of S. frugiperda and S. eridania and at $19^{\circ} \mathrm{C}$ on eggs of S. cosmioides (Table 2). There were no significant differences among the studied hosts when they were compared at the temperature range of $25-31^{\circ} \mathrm{C}$. At the two lowest temperatures ( 19 and $22^{\circ} \mathrm{C}$ ), however, S. eridania had a higher number of parasitized eggs by $T$. remus than $S$. 


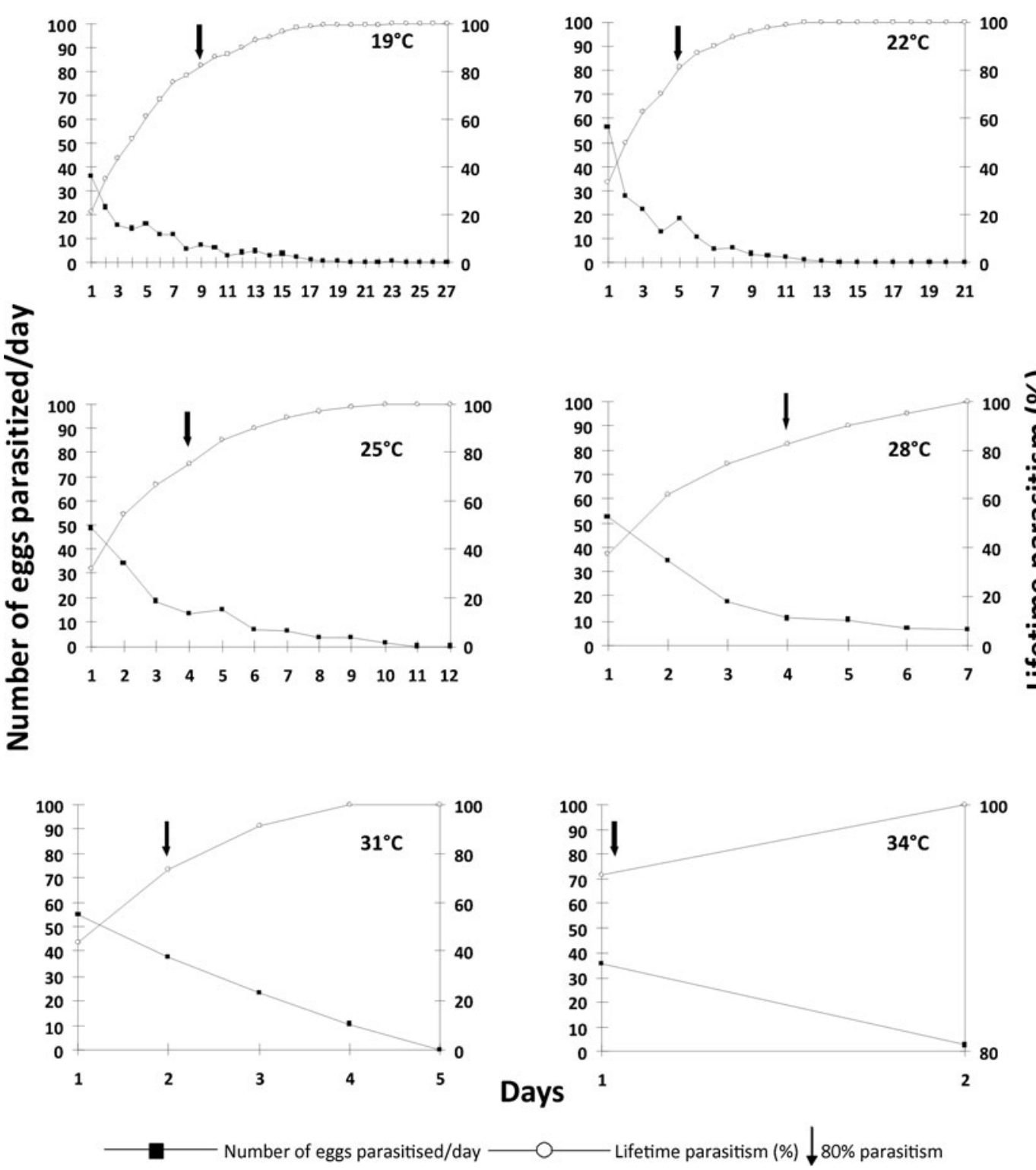

Fig 3 Daily (number) and lifetime parasitism (percentage) of Spodoptera eridania eggs by Telenomus remus at different temperatures.

frugiperda and S. cosmioides. At $34^{\circ} \mathrm{C}$, the highest number of parasitized eggs was observed for $S$. cosmioides (Table 2).

\section{Discussion}

The parasitization activity of $T$. remus always peaked in the first $24 \mathrm{~h}$ of parasitism regardless of the temperature and host species, similar to what has been reported for this species when attacking S. frugiperda (Hernández \& Diaz 1995, Bueno et al 2010a). These results indicate that $T$. remus is a pro-ovigenic species as females eclose with their full or nearly full egg complement (Mills \& Kuhlmann 2000), allowing females to parasitize as soon as they emerge.
The concentration of the parasitization activity in the first days of life is not a characteristic only common to $T$. remus, but also to other egg parasitoids, which need to quickly find their hosts and assure the allocation of their progeny. Oviposition peak of different species of egg parasitoids from the genus Trichogramma, for example, have been already reported in the literature on the first day after adult emergence (Pak \& Oatman 1982, Bai et al 1992, Volkoff \& Daumal 1994).

Not only oviposition peak can vary as a consequence of pro-ovigenic or synovigenic reproductive strategy, but also due to changes in parasitoid behavior (Denis et al 2011). For ectotherm parasitoids, temperature is inversely related to their metabolic rate and lipid consumption (Huey \& 
Table 1 Parental longevity of Telenomus remus females when presented with eggs of Spodoptera frugiperda, Spodoptera cosmioides, and Spodoptera eridania at different temperatures, $70 \pm$ $10 \% \mathrm{RH}$, and $12 / 12 \mathrm{~h}$ photoperiod (L/D).

\begin{tabular}{|c|c|c|c|}
\hline \multirow{2}{*}{$\begin{array}{l}\text { Temperature } \\
\left({ }^{\circ} \mathrm{C}\right)\end{array}$} & \multicolumn{3}{|c|}{ Parental adult longevity (days $\pm \mathrm{SE})^{\mathrm{a}}$} \\
\hline & $\begin{array}{l}\text { Spodoptera } \\
\text { frugiperda }\end{array}$ & $\begin{array}{l}\text { Spodoptera } \\
\text { cosmioides }\end{array}$ & $\begin{array}{l}\text { Spodoptera } \\
\text { eridania }\end{array}$ \\
\hline 19 & $21.17 \pm 0.60 a B^{a}$ & $26.44 \pm 1.44 \mathrm{aA}$ & $18.70 \pm 0.95 \mathrm{aC}$ \\
\hline 22 & $10.77 \pm 0.45 b C$ & $13.11 \pm 0.86 \mathrm{bA}$ & $11.40 \pm 0.88 \mathrm{bAB}$ \\
\hline 25 & $8.30 \pm 0.62 \mathrm{cB}$ & $13.11 \pm 0.68 \mathrm{bA}$ & $8.00 \pm 0.54 \mathrm{cB}$ \\
\hline 28 & $5.73 \pm 0.35 \mathrm{~dB}$ & $9.11 \pm 0.38 \mathrm{cA}$ & $4.85 \pm 0.30 \mathrm{~dB}$ \\
\hline 31 & $4.67 \pm 0.36 \mathrm{~dB}$ & $7.11 \pm 0.56 \mathrm{cA}$ & $3.25 \pm 0.29 \mathrm{deB}$ \\
\hline 34 & $2.37 \pm 0.25 \mathrm{eA}$ & $2.78 \pm 0.40 \mathrm{dA}$ & $1.50 \pm 0.14 \mathrm{eA}$ \\
\hline CV (\%) & 29.44 & & \\
\hline
\end{tabular}

${ }^{a}$ Means ( \pm standard error) followed by the same small letter in the column and the same capital letter in the line are not statistically different between each other by the Tukey's test at 5\% probability.

Berrigan 2001). Thus, lipids accumulated during the larval stage determine adult lifespan and fecundity (Visser \& Ellers 2008) and, therefore, its lifetime reproductive success (Huey \& Berrigan 2001). Because foraging decisions might be affected by the lipid reserves and the number of mature eggs (Godfray 1994), lipids carried over from the larval stage can be allocated to either egg production or to adult lipid reserves, leading to a trade-off between reproduction and adult survival (Pexton \& Mayhew 2002). Therefore, the time for how long parasitoids are active and, most importantly, the time required to reach $80 \%$ of their expected lifetime fecundity in the field might vary due to differences in temperature (Reznik \& Vaghina 2006),

Table 2 Lifetime number of parasitized eggs of Spodoptera frugiperda, Spodoptera cosmioides, and Spodoptera eridania by Telenomus remus at different temperatures, $70 \pm 10 \% \mathrm{RH}$, and 12/ $12 \mathrm{~h}$ photoperiod (L/D).

Temperature Lifetime number of parasitized eggs/female $( \pm S E)^{a, b}$

$\left({ }^{\circ} \mathrm{C}\right)$

\begin{tabular}{lll}
\hline $\begin{array}{l}\text { Spodoptera } \\
\text { frugiperda }\end{array}$ & $\begin{array}{l}\text { Spodoptera } \\
\text { cosmioides }\end{array}$ & $\begin{array}{l}\text { Spodoptera } \\
\text { eridania }\end{array}$ \\
\hline $124.90 \pm 8.23 \mathrm{aB}$ & $57.16 \pm 4.33 \mathrm{cC}$ & $166.99 \pm 8.07 \mathrm{aA}$ \\
$134.57 \pm 8.82 \mathrm{aAB}$ & $103.53 \pm 13.21 \mathrm{abcB}$ & $163.37 \pm 8.34 \mathrm{aA}$ \\
$140.80 \pm 8.46 \mathrm{aA}$ & $115.31 \pm 6.34 \mathrm{abA}$ & $139.48 \pm 10.58 \mathrm{abA}$ \\
$124.19 \pm 6.03 \mathrm{aA}$ & $132.06 \pm 7.49 \mathrm{aA}$ & $115.51 \pm 9.21 \mathrm{bA}$ \\
$111.40 \pm 7.92 \mathrm{aA}$ & $115.64 \pm 16.76 \mathrm{abA}$ & $111.10 \pm 10.58 \mathrm{bA}$ \\
$35.40 \pm 6.45 \mathrm{bB}$ & $61.46 \pm 2.34 \mathrm{bcA}$ & $36.90 \pm 4.88 \mathrm{cB}$ \\
20.28 & & \\
& &
\end{tabular}

${ }^{a}$ Means ( \pm standard error) followed by the same small letter in the column and the same capital letter in the line are not statistically different between each other by the Tukey test at $5 \%$ probability.

${ }^{b}$ Original means followed by statistics performed on data transformed by $\sqrt{X+0.5}$. hosts (Reznik et al 2001), or parasitoid species (Pizzol et al 2010) or due to a combination of more than one of these factors. These differences might be directly responsible for their parasitization capacity and consequently to their chances to succeed as a biological control agent. Thus, whether parasitization is more concentrated in the first days of life or evenly distributed throughout adulthood is an important characteristic to be considered when choosing the strategy for parasitoid release (Bueno et al 2010a).

In the field, parasitoids are exposed to biotic and abiotic factors that can affect their fitness, such as the contact with chemicals sprayed for the crop management or an abrupt change in temperature (Carmo et al 2010, Denis et al 2011), that will easily affect the natural enemy but hardly ever kill the pests. Egg parasitoids are usually tiny little wasps more susceptible to the chemicals used in agriculture as herbicides and fungicides than their hosts (Carmo et al 2010). This is a crucial parasitoid feature that needs to be taken into consideration in the biological control program strategy.

Telenomus remus reached $80 \%$ of its lifetime parasitization capacity from 1 to 9 days in all temperatures and hosts tested, which are much earlier than other egg parasitoids already used in Spodoptera control (Bueno et al 2008). Therefore, any pesticide spraying needed after $T$. remus release should be performed after that period of time, otherwise $T$. remus performance might be impaired, and this period of time will vary with parasitoid species (Bueno et al 2010b, 2012).

Female longevity was inversely proportional to temperature as expected and similar to what has been already published for this parasitoid (Hernández \& Diaz 1995, Bueno et al 2010a). Thus, it is possible that in warm regions, the mean longevity of the natural enemies may be reduced in field conditions, suggesting that biological control programs using $T$. remus in those regions might demand a higher frequency of releases than in regions with cooler temperatures.

Female longevity can also have a direct impact on lifetime parasitization capacity, a trait directly affected by temperature. The higher lifetime parasitization observed at lower temperatures $\left(19,22\right.$, and $\left.25^{\circ} \mathrm{C}\right)$ for $T$. remus parasitizing eggs of $S$. eridania and $S$. frugiperda can be explained by the higher parental longevity of $T$. remus females at those temperatures. According to Gerling (1972), females of T. remus live longer at lower temperatures as a consequence of the decreased metabolic rate observed at cold temperatures.

On eggs of S. cosmioides, on the other hand, T. remus had the lowest lifetime parasitization at both extreme temperatures $\left(19\right.$ and $34^{\circ} \mathrm{C}$ ), indicating this particular host is not as suitable to $T$. remus at these temperatures as compared to the others. These results indicate that different hosts offer different degrees of protection against temperature changes. Furthermore, it is important to consider that these extreme temperatures might be close to the lower and 
upper thermal limits for the parasitoid development. Bueno et al (2008) reported that the lower thermal limit for $T$. remus reared on eggs of $S$. frugiperda is $12.5^{\circ} \mathrm{C}$.

Gupta \& Pawar (1985) had already reported the influence of temperature on parasitism capacity of $T$. remus on Spodoptera litura eggs and reported that the highest parasitization rates were obtained between 20 and $25^{\circ} \mathrm{C}$. Bueno et al (2010a) also found similar results and emphasized that the highest lifetime parasitism of $T$. remus on eggs of $S$. fugiperda was observed at $20^{\circ} \mathrm{C}$.

A relevant aspect that may help to explain the differences observed on the parasitization efficiency is related to the differences among the host species studied and the structure of their egg masses (Pomari et al 2012). Spodoptera eridania eggs are laid in a single layer, thus facilitating parasitism, while eggs of $S$. frugiperda and $S$. cosmioides are laid in several layers of superposed eggs, thus demanding higher energetic expenditure from the parasitoid to parasitize the inner layers of eggs.

In conclusion, the parasitoid exhibits considerable parasitism capacity even at the extreme tested temperatures (19 and $34^{\circ} \mathrm{C}$ ). It suggest that $T$. remus can be well adapted to environments with such thermal conditions and an alternative to control $S$. eridania, $S$. cosmioides, and $S$. frugiperda, as all of these hosts were successfully parasitized. However, it is important to emphasize that additional field studies are needed in order to propose the implementation of a biological control program using this egg parasitoid. Moreover, there is still the need to investigate several bioecological traits (dispersal capacity, for example) and the best parasitoid release strategy (number of parasitoids to be released/host egg, interval between releases) to allow for the successful use of this biological control agent in the field.

Acknowledgments Thanks are also extended to Journal Experts Editor for the English revision and to Adair V. Carneiro, laboratory assistant, for helping conducting the trials. The authors would like to thank EMBRAPA, CAPES, and CNPq for the financial support that made this research possibleThis paper was approved for publication by the Editorial Board of Embrapa Soja.

\section{References}

Bai B, Luck RF, Forster L, Stephens B, Janssen JAM (1992) The effect of host size on quality attibutes of the egg parasitoid, Trichogramma pretiosum. Entomol Exp Appl 64:37-48

Bleicher E, Parra JRP (1990) Espécies de Trichogramma parasitoides de Alabamma argilacea. II. Tabela de vida de fertilidade e parasitismo de três populações. Pesq Agrop Bras 25:207-214

Bueno RCOF, Carneiro TR, Pratissoli D, Bueno AF, Fernandes OA (2008) Biology and thermal requirements of Telenomus remus reared on fall armyworm Spodoptera frugiperda eggs. Ciência Rural 38:1-6
Bueno RCOF, Carneiro TR, Bueno AF, Pratissoli D, Fernandes OA, Vieira SS (2010a) Parasitism capacity of Telenomus remus Nixon (Hymenoptera: Scelionidae) on Spodoptera frugiperda (Smith) (Lepidoptera: Noctuidae) eggs. Braz Arch Biol Technol 53:133-139

Bueno RCOF, Bueno AF, Pratissoli D, Parra JRP, Vieira SS, Oliveira LJ (2010b) Biological characteristics and parasitism capacity of Trichogramma pretiosum Riley (Hymenoptera, Trichogrammatidae) on eggs of Spodoptera frugiperda (J. E. Smith) (Lepidoptera, Noctuidae). Rev Bras Entomol 54:322-327

Bueno RCO, Parra JRP, Bueno AF (2012) Trichogramma pretiosum parasitism of Pseudoplusia includens and Anticarsia gemmatalis eggs at different temperatures. Biol Control 60:154-162

Burr IW, Foster LA (1972) A test for equality of variances. Mimeo series no. 282. University of Purdue, West Lafayette, $26 \mathrm{p}$

Carmo EL, Bueno AF, Bueno RCOF (2010) Pesticide selectivity for the insect egg parasitoid Telenomus remus. BioControl 55:455-464

Cave RD (2000) Biology, ecology and use in pest management of Telenomus remus. Biocontrol 21:21-26

Cruz I, Figueiredo MLC, Oliveira CE, Vasconcelos CA (1999) Damage of Spodoptera frugiperda (Smith) in different maize genotypes cultivated in soil under three levels of aluminium saturation. Int J Pest Manag 45:293-296

Denis D, Pierre JS, van Baaren J, van Alphen JJM (2011) How temperature and habitat quality affect parasitoid lifetime reproductive success-a simulation study. Ecol Model 222:1604-1613

Desneux N, Decourtye A, Delpuech JM (2007) The sublethal effects of pesticides on beneficial arthropods. Annu Rev Entomol 52:81-106

Diez-Rodriguez GI, Omoto C (2001) Herança da resistência de Spodoptera frugiperda (J. E. Smith) (Lepidoptera: Noctuidae) à lambda-cialotrina. Neotrop Entomol 30:311-316

Ferrer $F$ (2001) Biological control of agricultural insect in Venezuela: advances, achievements, and future perspectives. Biocontrol 22:67-74

Figueiredo MLC, Della Lucia TMC, Cruz I (1999) Controle integrado de Spodoptera frugiperda (Smith \& Aboth) utilizando-se do parasitoide Telenomus remus Nixon. Pesq Agrop Bras 34:1975-1982

Figueiredo MLC, Della Lucia TMC, Cruz I (2002) Effect of Telenomus remus Nixon (Hymenoptera: Scelionidae) density on control of Spodoptera frugiperda (Smith) (Lepidoptera: Noctuidae) egg masses upon release in maize field. Rev Bras Milho e Sorgo 1:12-19

Frazer BD, McGregor RR (1992) Temperature-dependent survival and hatching rate of eggs of seven species of Coccinelidae. Can Entomol 124:305-312

Gerling D (1972) The developmental biology of Telenomus remus Nixon (Hym.: Scelionidae). Bul Entomol Res 61:385-488

Godfray HCJ (1994) Parasitoids: behavioural and evolutionary ecology. Princeton University Press, Princeton, New Jersey

Gupta M, Pawar AD (1985) Multiplicatin of Telenomus remus Nixon on Spodoptera litura (Fabricius) reared on artificial diet. J Adv Zool 6:13-17

Greene GL, Leppla NC, Dickerson WA (1976) Velvetbean caterpillar: a rearing procedure and artificial medium. J Econ Entomol 69:487-488

Hernández D, Diaz F (1995) Efecto de la edad del parasitoide Telenomus remus Nixon (Hymenoptera: Scelionidae) sobre su capacidad de ovipostura y proporción sexual de la descendencia. Bol Entomol Venez 10:161-166

Hernández D, Díaz F (1996) Efecto de La temperatura sobre EI desarrollo de Telenomus remus Nixon (Hymenoptera: Scelionidae) parasiotide de Spodoptera frugiperda (Smith) (Lep.: Noctuidae). Bol Entomol Venez 11:149-153

Hernández D, Ferrer F, Linares B (1989) Introdución de Telenomus remus Nixon (Hym.: Scelionidae) para controlar Spodoptera frugiperda (Lep.: Noctuidae) en Yaritagua, Venezuela. Agron Trop 39:199-205

Higley LG, Pedigo LP, Ostlie KR (1986) Degray: a program for calculation degree-days, and assumptions behind the degree-day approach. Environ Entomol 15:999-1016

Huey RB, Berrigan D (2001) Temperature, demography, and ectothermic fitness. Amer Nat 158:204-210 
Mills NJ, Kuhlmann U (2000) The relationship between egg load and fecundity among Trichogramma parasitoids. Ecol Entomol 25:315-324

Morales J, Gallardo JS, Vásquez C, Ríos Y (2000) Patrón de emergencia, longevidad, parasitismo y proporción sexual de Telenomus remus (Hymenoptera: Scelionidae) com relación al cogollero Del maíz. Bioagro 12:47-54

Nagoshi RN (2009) Can the amount of corn acreage predict fall armyworm (Lepidoptera: Noctuidae) infestation levels in nearby cotton? J Econ Entomol 102:210-218

Pak GA, Oatman ER (1982) Biology of Trichogramma brevicapillum. Entomol Exp Appl 32:61-67

Pexton JJ, Mayhew PJ (2002) Siblicide and life-history evaluation in parasitoids. Behav Ecol 13:690

Pizzol J, Pintureau B, Khoualdia O, Desneux N (2010) Temperaturedependent differences in biological traits between two strains of Trichogramma cacoeciae (Hymenoptera: Trichogrammatidae). J Pest Sci 83:447-452

Pogue GM (2002) A world revision of the genus Spodoptera Guenée (Lepidoptera: Noctuidae). Mem Amer Entomol Soc 43:1-202

Pomari AF, Bueno AF, Bueno RCOF, Menezes AO Jr (2012) Biological characteristics and thermal requirements of the biological control agent (Hymenoptera: Platygastridae) reared on eggs of different species of the genus (Lepidoptera: Noctuidae). Ann Entomol Soc Am 105:73-81

Reznik SYA, Vaghina NP (2006) Temperature effects on induction of parasitization by females of Trichogramma principium (Hymenoptera, Trichogrammatidae). Entomol Rev 86:133-138
Reznik SYA, Umarova TYA, Voinovich ND (2001) Long-term egg retention and parasitization in Trichogramma principium (Hymenoptera, Trichogrammatidae). J Appl Entomol 125:169-175

Santos GP, Cosenza GW, Albino JC (1980) Biologia de Spodoptera latifascia (Walk., 1856) (Lepidoptera: Noctuidae) sobre folhas de eucalipto. Rev Bras Entomol 24:153-155

SAS Institute (2001) User's guide: statistics, version 8e. SAS Institute, Cary, NC

Shapiro SS, Wilk MB (1965) An analysis of variance test for normality. Biometrika 52:591-611

Silva AGA, Gonçalves CR, Galvão DM, Gonçalves AJL, Gonçalves J, Silva MM, Simoni L (1968) Quarto catálogo dos insetos que vivem nas plantas do Brasil: seus parasitos e predadores. Parte II, 1 tomo, Insetos, hospedeiros e inimigos naturais. Ministério da Agricultura, Rio de Janeiro, $622 \mathrm{p}$

Stark JD, Banks JE (2003) Population-level effects of pesticides and other toxicants on arthropods. Ann Rev Entomol 48:505-519

van Lenteren JC, Bueno VHP (2003) Augmentative biological control of arthropods in Latin America. Biocontrol 48:123-139

Visser B, Ellers J (2008) Lack of lipogenesis in parasitoids: a review of physiological mechanisms and evolutionary implications. J Ins Physiol 54:1315-1322

Volkoff AN, Daumal J (1994) Ovarian cycle in immature and adult stages of Trichogramma cacoeciae and T. brassicae (Hym. Trichogrammatidae). Entomophaga 39:303-312

Zalucki MP, Adamson D, Furlong MJ (2009) The future of IPM: whither or wither? Aust J Entomol 48:85-96 